\title{
Innovation models and technological parks: interaction between parks and innovation agents
}

\author{
Hilka Vier Machado ${ }^{1 *}$, Fábio Lazzarotti ${ }^{1}$, Fernando Fantoni Bencke ${ }^{1}$
}

\begin{abstract}
Technological parks are strategic innovation places for the stimulation of synergy among different agents. Current theoretical study identifies forms of interactions between technological parks and agents mentioned in interactive models of innovation. Foregrounded on triple, quadruple e quintuple helix models, current analysis investigates interactions of parks with companies, universities, government, civil society and the natural environment. One of the main contributions of current study is the integrating approach of interactions between parks and agents mentioned in innovation models. Overall interaction, provided in the results, favors the visualization of the parks' management dynamics and the implementation of innovation models. Its practical contribution comprises subsidies for the construction of strategies, definition of stakeholders' management and elaboration of good practices for technological parks.
\end{abstract}

Keywords: technological parks; innovation; innovation models; innovation agents.

Submitted: April 23 $3^{\text {rd }}, 2018$ / Approved: July 6 ${ }^{\text {th }}, 2018$

\section{Introduction}

Innovation is one of the main factors in current socio-economical dynamics. One of the characteristics of innovation production comprises interdependence between organizations and interdisciplinarity. Several institutions influence the innovation process (Edquist, 2005), among which technological parks may be mentioned. Technological Parks (TPs) may be defined as "a planned complex for entrepreneur and technological development, triggering innovation culture, industrial competitiveness, entrepreneurs' capacitation and promotion of synergies in scientific research, technological and innovation development between companies and ICTs, with or without any bonding" (Brasil, 2016). Parks are not merely productive, scientific and technical sites based on the presupposition of co-location. They are also educational sites due to their production of knowledge. They are dependent on social, political, institutional and cultural interrelationships (Hommen et al., 2006).

Many TPs receive money from the government for their activities. Since they are complex structures, they require huge investments at the start and throughout their entire development (Lee, Hung, 2003). Financial resources are not limited to their establishment but also to their growth due to their continuous growing trends. According to Lee \& Hung (2003), TPs' growth does not merely need investments for infrastructure and personnel but also for solutions in water supply, internal traffic and mechanisms for environmental protection.

Since society considers TPs as pillars of technological innovation and transference, it also expects from them the promotion of innovation, the launching of new products and penetration into new markets (Löfsten, Lindelof, 2002). It is expected that they make easier the establishment of firms and contribute toward boosting small enterprises. Consequently, TPs trigger technological development and economic growth (Hansson, Husted, Vestergaard, 2005; Vedovello, Judice, Maculan, 2006), and attend to the interests of the agents involved (Löfsten, Lindelof, 2002) as they build a synergic relationship with the latter (Guan, Zhao, 2013).

Management and assessment of parks is a rather complex matter (Bigliardi et al., 2006; Hauser et al., 2015; Ribeiro et al. 2016). Further, their activities should be ordered by innovation models which form the basis on which innovation is produced. Interactive models are currently predominant (Conde, Araújo-Jorge, 2003; Etzkowitz, Leydesdorff, 2000). The triple helix model (Etzkowitz, Leydesdorff, 2000) is the most widespread, even though others, such as the quadruple and quintuple models have also been established (Carayannis et al., 2012).

Since TPs, as innovation sites, influence research and development results (Schmidt et al. 2016), they have to ensure a synergic relationship with the agents (Guan, Zhao, 2013) within the context of innovation models. Current theoretical study identifies interaction forms, given in the literature, between parks and agents mentioned in the innovation models to contribute towards the comprehension of park dynamics according to the laws of innovation models.

The second section of the study discusses TPs and the Triple, Quadruple and Quintuple Helix innovation Models. Further, in-depth discussions and investigations involve Triple, Quadruple and Quintuple helix innovation models and their expected interaction forms.

\section{Some thoughts on Technological Parks}

Technological Parks boost technological development and contribute towards the establishment and transference of new technologies. They are hybrid institutions that agglutinate research and development agents (Carayannis, Rakhmatullin, 2014). Some of their aims

(1) Universidade do Oeste de Santa Catarina (UNOESC), Brasil

Corresponding author: hilkavier@yahoo.com 
comprise help in the development and growth of technology-based firms, transfer of knowledge between universities and firms, and boosting of the development of products and innovating processes (Felsenstein, 1994).

Technological Parks were introduced in the United States in the 1950s and in a short period became worldwide, with current 500 units spread throughout the planet (UNESCO, 2016). The first initiatives in Brazil emerged in 1985, featuring fast expansion. There were 42 parks in Brazil in 2005 (ANPROTEC, 2006) and 94 in 2015 (ANPROTEC, 2015).

The TPs' implementation and management may be affected by the local and regional context (Audy, 2014; Quintas, Wield, Massey, 1992). The establishment and implementation processes of a TP require the commitment of agents involved within a long-term vision (Lastres, Cassiolato, 2003), which may be perceived in variegated institutional and juridical setups. For instance, they may be established for profit or as charities, as total or partial property of a university, or as private institutions. They may be legally constituted as foundations, mixed economy societies or social organizations (Pessôa et al., 2012).

The functioning of Technological Parks depends on physical and service infrastructures, innovation strategies and management practices, including market activities that ensure communication abilities and image construction to attract investors and firms. Further, they require data systems on clients, suppliers and market performance (Bibliardi et al. 2006; Hauser et al., 2015). Network incentives involving multiinterest participants (Autio, 2000; Bellavista, Sanz, 2009), such as companies, universities and other stakeholders (Hansson, 2007; Villasalero, 2014), are also part and parcel of park management through formal or informal bonds with universities, and private companies (Link, Scott, 2006). Specifically with regard to administration and relationships, the park management must "enhance integration between internal agents and the permanent interactivity with external partners, especially those related to companies already working in the park. Success of such dynamic synergy may attract a greater number of agents for the park's neighboring areas by establishing potential conditions for the development of an associated cluster or within the same region" (Giugliani et al. 2012, p. 45). They have the duty to warrant innovation with several agents. Specific administration is thus required, such as stakeholder management, a strategic relationship that include collaboration, involvement and monitoring of agents who differ in interest and capacity for relationship (Pacagnella Jr. et al. 2015).

As a rule, TPs' success depends on macro level factors, such as the national and regional contexts and a strategic policy of innovation. They also depend on micro level factors, such as management, physical space, the environment of park and incubated firms, management and relationships.

In fact, the expansion and complexity of parks triggered several research works. In their bibliometric study, including publications between 1990 and 2015 on incubators and parks, Diez-Vial and Montoro-Sanchez (2017) identified four research periods: a) initial period: research comprised themes associated with internal relationships, management, support and entrepreneurs (1996-2000);

b) growth period: themes included transfer of technology, regional development and others (2001-2005);

c) opening period, involving park performance, universities, transfer of technology and strategies, for instance (2006-2010);

d) consolidation period (2011-2015).

Diez-Vial and Montoro-Sanchez (2017) informed that previous studies did not include any approach associating parks with innovation models.

\section{Innovation models}

The welfare of society is the paradigm of $21^{\text {st }}$ century science. It is produced by a network of agents and through several and different modes (Velho, 2011). It differs from former concepts of science delineated in linear models. Innovation through linear models was the result of a series of stages within a linearity that focused on production and not on the continuous social process. On the contrary, interactive models link interactivities between companies, people and Science-Technology-Innovation system. Innovation was the result of feedback between the different phases and the several interactivities between Science, Technology and the Innovation process (Conde, Araújo-Jorge, 2003). The Triple Helix is considered to be the forerunner of the other interactive models.

\subsection{Triple Helix}

Proposed by Etzkowitz \& Leydesdorff (2000) and represented by three intertwining helixes (universities, industry and government), the Triple Helix Model is the most popular of the interactive models. Its main feature is the change that universities boost for company innovation to the extent that companies are guided towards research. This fact may be confirmed by exponential world expansion which occurred in the 1980s, number of patents, warrants, spinoffs and Research and Development (R\&D) contracts, especially in the US, Europe and Japan (Villasalero, 2014).

The Triple Helix Model insists that the interaction between university, government and companies triggers the development of innovation within different contexts and results in a complex collaboration which produces different dynamics according to the region concerned. Innovation is not the result of a priori synchronization (Conde, Araújo-Jorge, 2003; Etzkowitz, Leyesdorff, 2000). According to Luengo \& Obeso (2013), the model may be prescribed because it triggers the process; it is describable since it acknowledges the cases in which innovation was successful. Etzkowitz \& Leydesdorff (2000) insist that innovation sources do not have a predefined order but produce issues whose solutions may be sought by participants, analysts and policy formers. The helix represented by the company is the source of goods and service production. The helix representing the government is the agent that warrants the stability of contractual relationships, providing norms, laws and policies. Luengo \& Obeso (2013) remark that 
the government has a direct role in directing resources and an indirect one by funding research centers and universities. On the other hand, the helix representing the university or research institutions is the source of knowledge and technology.

According to Etzkowitz \& Leydesdorff (2000), the model is expected to be neither stable nor determined. It is expected to generate difficult situations whose solutions are sought by participants, analysts and policy makers. The same authors (2000: 118) enhance that the Triple Helix Model "does not consist merely in the university-company-government relationship but also in the internal transformation of each sphere". In other words, innovation has to produce changes in the agents. Communication and negotiations among the agents produce a layer that increasingly reorganizes the underlying agreements. However, the negotiation process is complex and dynamic. Etzkowitz \& Leydesdorff (2000: 1) state that the Triple Helix Model "differs from the national system of innovation", proposed by Nelson (1993), and by Ludvall (1988) who insist that "the company has a leading role in innovation". It differs from the Sabato's Triangle Model which privileges the State. According to the authors, the Triple Helix Model enhances the central role of the university in innovation, focusing on the overlying forms of network communication which redefine institutional arrangements between universities, industries and government departments.

The generation of innovation in the Triple Helix Model is the product of the integrated activity between universities, industries and government. As from the above model, forms of interaction between agents, or rather, universities, companies and government, and technological parks, are identified.

\subsubsection{Interaction between parks and firms}

As a rule, companies established in TPs have several advantages when compared to those outside them (Löfsten, Lindelöf, 2002). A favorable effect on companies is the park's image (Ferguson, Olofsson, 2004), although there is no agreement on the issue (Chan, Lau, 2005). Another possible effect on companies is the contribution for better accessibility to information (Löfsten, Lindelöf, 2002). Schmidt et al. (2016) comment that parks' contribution may be achieved even prior to the companies' establishments, starting from the construction of business plans. Other studies showed several activities as interactions between parks and companies:

a) Increase of the companies' intellectual capital: the parks' infrastructure and dynamics accumulate knowledge and increase intellectual capital through qualification-raising of workers (Koh, Koh, Tschang, 2005) and training programs (Chan, Lau, 2005);

b) the companies' survival rate: Ferguson \& Olofsson (2004) insist that companies in Technological Parks have greater survival rates that those outside. Greater cooperation between companies installed in Parks and universities is one of the factors of survival, even though profits due to their activities in Parks cannot be calculated (Löfsten, Lindelöf, 2002); c) companies' growth rates. The Parks' management may be an asset in the growth of companies within Parks (Detwiller, Lindelöf, Löfsten, 2006; Löfsten, Lindelöf, 2004);

d) internationalization of companies and the establishment of worldwide connections (Lee, Hung, 2003). Management of Parks enhances cooperation networks with national and international agents in search for partners, favoring the internationalization of companies in the Parks:

e) development of products: Chan \& Lau (2005) identified the importance of supporting research in Parks and facilities for tests on the development of products as the main advantage indicated by companies;

f) innovation and number of patents by companies: Lindelöf \& Löfsten (2002) did not identify significant differences with regard to the number of patents obtained by companies, either in Parks or outside them. On the other hand, Siegel (apud Phan, Siegel, Wright, 2005) revealed that companies installed in Parks are more efficient with regard to the production of new products, services and patents. According to Campanella et al. (2014), the great number of research laboratories indicates the number of patents. Parks may contribute by assisting companies to obtain intellectual property, research funds, and furnish labs and specialized personnel for the development of products (Schmidt et al., 2016; Vedovello, 2006). Further, Luengo \& Obeso (2013) insist that Parks may increase data sources for companies and, thus, their innovation capacity;

g) participation in networks: Cooperation between big and small companies, between the latter and stakeholders, scientists and society, in general, occurs within TPs (Campanella et al., 2014);

h) market achievement for innovation products: According to Koh, Koh and Tschang (2005), TPs' activities must provide companies' integration with the local and global markets, and identify market niches as technological companies, especially small and medium-sized ones, have to cope with difficulties to introduce innovations in the markets, gain markets and broadcast innovatory products. Schmidt et al. (2016) state that TPs may offer assistance in market research, study distribution channels and assist in price formation;

i) industrialization and reuse programs: Parks may development and implement programs in fields that would help companies to produce and re-adequate production when innovation becomes obsolete $(\mathrm{Bi}$ gliardi et al., 2006);

j) Contracts with stakeholders: Contracts may help companies installed in TPs for the prospection of stakeholders (Campanella et al., 2014; Schmidt et al., 2016).

Table 1 gives a synthesis of the above aspects in Technological Parks. 
Table 1: Types of interactivities between Technological Parks and Companies

\begin{tabular}{|c|c|}
\hline Types of Interaction between TPs with Companies & Authors \\
\hline Development of new products and innovatory products. & Felsenstein (1994); Löfsten \& Lindelöf 2002); Chan, Lau (2005). \\
\hline Protection of Property Rights (patents). & Siegel, apud Phan, Siegel, Wright (2005); Campanella et al. (2014). \\
\hline Enhancement to internationalization and establishment of worldwide connections. & Lee, Hung (2003) \\
\hline Support for market achievement for new products and innovatory products. & Chan \& Lau (2005); Koh, Koh, Tschang (2005); Schmidt et al (2016). \\
\hline Contribution of TPs' image on companies. & Ferguson, Olofsson (2004). \\
\hline Broadening of companies' growth and survival rates. & $\begin{array}{l}\text { Ferguson, Olofsson (2004); Detwiller, Lindelöf; Löfsten (2006); Löfsten, } \\
\text { Lindelöf (2004). }\end{array}$ \\
\hline Contracts with stakeholders. & Campanella et al. (2014). \\
\hline Broadening of data accessing. & Löfsten, Lindelöf (2002); Luengo \& Obeso (2013) \\
\hline Increase in intellectual capital and training programs. & Koh,Koh, Tschang (2005); Chan \& Lau (2005). \\
\hline Development of reuse programs to adequate production to obsolete innovation. & Bigliardi et al. (2006) \\
\hline Enhancement of networks between companies and other institutions & Campanella et al., (2014) \\
\hline
\end{tabular}

Source: prepared by the authors.

\subsubsection{Interaction between Parks and Universities}

Scanty information exists on the activities of universities in Technological Parks (Hommen et al., 2006). According to Vedovello et al. (2006), when universities install themselves in TPs, they expect to commercialize the product of their researchers, obtain further financial sources, and widen the labor market for researchers and students. Universities expect that TPs establish a milieu for selling their technologies and a place in which spinoffs prosper (Diez-Vial; MontoroSanchez, 2017).

However, Villasalero (2014) identified that Universities have an important, albeit passive role, since they do not have a leadership role in TPs. Collarino \& Torkomian (2015: 221) remark that "there are no strong bonds between TPs and Universities; in other words, minimum contacts, with few lectures, and few academic research works on the subject". Villasalero (2014) analyzed the transference of technology by 45 universities and also insisted on the universities' lowscale links with TPs. The author concluded that scientific knowledge produced in Universities mainly contributed towards technological capital of technology-based companies through non-monetary repercussions. Agreements on monetary transference were not identified. On the other hand, Chan \& Lau (2005) registered that companies in TPs attributed a greater relevance towards the development of their products to their relationships with Universities than to the Park's management.
Companies in TPs may benefit from informal interactivities and lectures, since their relationship with the university is non-monetary (Villasalero, 2014). Formal and informal interactivities with Universities increase the innovative capacity of companies in TPs (Díez-Vial, Montoro-Sánchez, 2016). TPs may provide Universities with classrooms, auditoriums, audiovisual equipments and funding (Schmidt et al. 2016). Universities may also have the benefit of signing agreements with TP companies (Campanella et al. , 2014).

Spinoffs production, the employment of undergraduate or postgraduate students in TPs and in companies installed in TPs are an asset to Universities (Hommen et al., 2006; Salvador, Rolfo, 2011). Ferrara, Lamperti \& Mavília (2016) identified that students expect work opportunities or may be seen as potential entrepreneurs. However, Villasalero (2014) pinpointed a negative relationship between the formation of doctoral candidates in Spanish Universities and the accumulation of technological capital by companies. The above actually evidences the low valorization of $\mathrm{PhDs}$ by companies.

The enhancement of networks that produce knowledge and innovation between companies and universities or between companies and other stakeholders is also the role of Park managements (Hansson, 2007; Villasalero, 2014). TPs have also the role of stimulating scientific production, obtaining patents, establishing agreements and technology warrants (Detwiller, Lindelöf, Löfsten, 2006). Table 2 provides a synthesis of the types of interactivities between TPs and Universities. 
Table 2: Types of interactivities between TPs and Universities

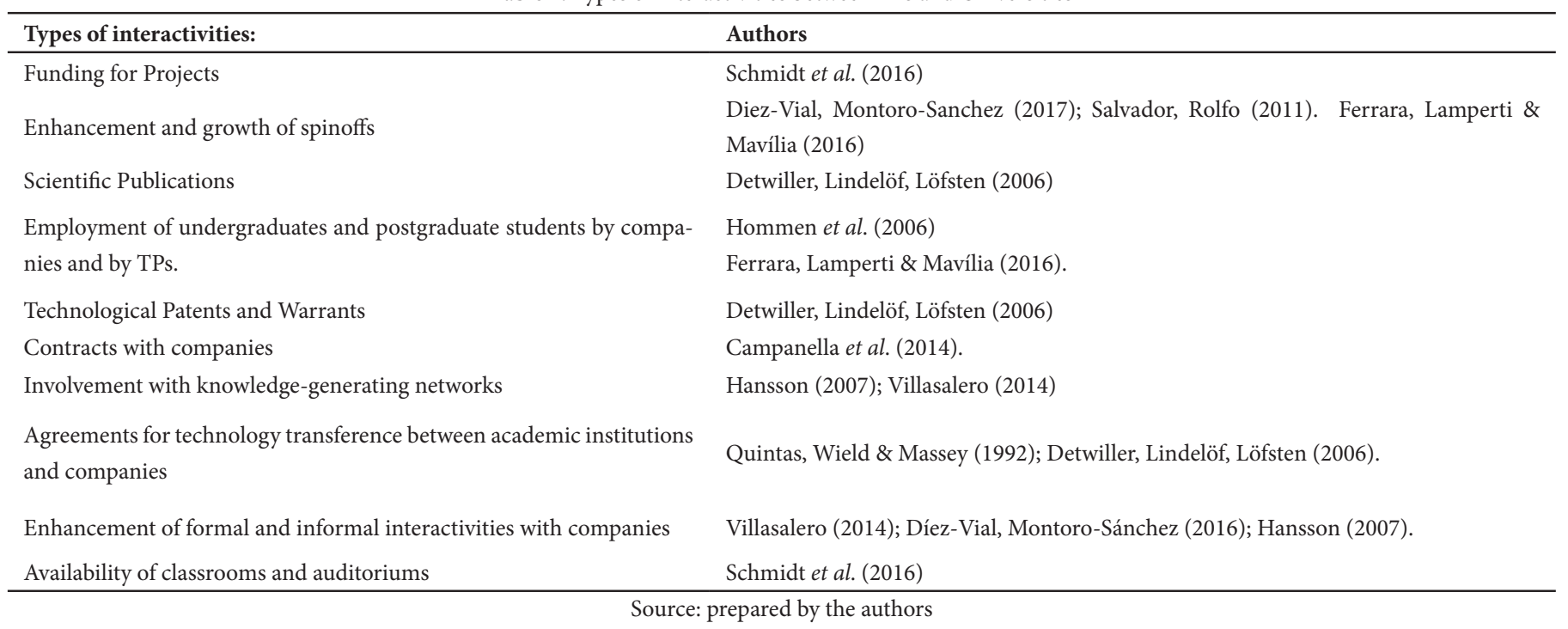

\subsubsection{Interactivities between TPs and the Government}

In the case of TPs, the government expects the capacity for innovation represented by patents, scientific publications (Fondé, Hussler, 2005) and the establishment of technology-based companies (Detwiller, Lindelöf, Löfsten, 2006). Another expected result is the exportation of innovatory products due to the internationalization of companies (Lee, Hung, 2003), which, in their turn, is the result of enhancement of technology-based, spinoff and startup companies (Campanella et al (2014).
Vedovello et al. (2006) and Löfsten \& Lindelof (2002) insist that governments expect that TPs produce innovations, revitalize economically degraded areas and generate employment. It is also expected that they attract stakeholders and investments in $R \& D$ activities.

Table 3: Types of interactivity between TPs and Government

\begin{tabular}{ll}
\hline Types of interaction between TPs and Government & Authors \\
\hline Concession of Patents & Fondé, Hussler (2005) \\
Scientific publications & Detwiller, Lindelöf, Löfsten (2006); Fonde, Hussler (2005). \\
Export of products and the internationalizations of companies & Lee, Hung (2003). \\
Establishment of technology-based, spinoff and startup companies & Bigliardi (2006); Campanella et al. (2014); Detwiller et al. (2006). \\
Generation of employment in the neighborhood & Löfsten, Lindelof (2002); Bigliardi et al. (2006); Vedovello et al. (2006). \\
Development of economically degraded regions & Vedovello et al. (2006); Lofsten \& Lindelof (2002). \\
Attraction of stakeholders and investments in R\&D activities & Vedovello et al. (2006); \\
\hline
\end{tabular}

Source: prepared by the authors

The Triple Helix Model establishes the manner central agents function within the innovation process, government, university and companies, whose types of interactivities have been provided in Tables 1, 2 and 3. However, Quadruple and Quintuple Helix models interact with other agents and will be discussed below.

\subsection{Quadruple Helix Model}

Diversity of context, the complexity of the innovation process and the participation of different actors were motifs for the emergence of critiques to the Triple Helix Model. Inclusion of only three dimensions to the model has a generic feature frequently representing a strict conceptual base to the theoretical reflection on innovation dynamics (Schoonmaker, Carayannis, 2013).
Consequently, Carayannis \& Rakhmatullin (2014) proposed the Quadruple Helix Model. Civil society or stakeholders constitute the new helix of the system (Carayannis, Campbell, 2009), or rather, negotiation and collaboration between stakeholders raise the regional innovation. The Quadruple Helix Model places innovation users within the center and encourages the innovation development inherent to them (Carayannis, Rakhmatullin, 2014). Consequently, the stakeholders' context and power affect innovation dynamics since relationships are characterized by coexistence of different modes of knowledge and innovation. Pluralism and diversity in knowledge and innovation are extant (Carayannis et al., 2012).

According to Mian, Lamine \& Fayolle (2016) and MacAdam, Miller \& MacAdam (2016), the Quadruple Helix Model introduces the 
commercial factor within the innovation model. However, Carayannis \& Rakhmatullin (2014) underscore that the model aims at empowering and connecting all the value makers of the innovation ecosystem, with a focus on the cooperation in innovation and in dynamic processes of competition, coevolution and co-specialization. Makers, users and suppliers of knowledge and technology are included among the innovation agents. "The Quadruple Helix Model implies a wider comprehension of the production of knowledge, involvement of culture, arts, media, values and life styles" (Carayannis, Rakhmatullin, 2014: 226).

In the case of the Quadruple Helix Model, stakeholders are not restricted to universities, companies and government, but to all who create value within the innovation ecosystem. Whereas TPs in the Triple Helix Model are related to "universities, research centers, entrepreneurs and the so-called academics - entrepreneurs, financial agents, venture capitalists, development agencies and authorities linked to the national, regional and local government - with their own different aims, expectations and interests" (Vedovello et al., 2006, p. 6), in the Quadruple Helix Model, a section of society participates in the dynamics, which may also include commercialization types. Consequently, stakeholders in the Quadruple Helix Model are represented by civil society and comprise: a) Research and Development (R\&D) agents, such as universities, companies and government; b) non-R\&D agents, such as those involved in design, production, marketing, sales, technology, incremental changes, utilization of knowledge for new applications, interaction between users, acquisition, patents, warrants, and others; c) hybrid institutions, such as consortia, centers of interdisciplinary research, support institutions (parks and incubators), financial support and stakeholders (venture capital, angel investment, seed capital, etc) (Carayannis, Rakhmatullin, 2014).

Since the types of interactions between TPs and universities, companies and government were discussed above within the Triple Helix Model, only the interactions with civil society will be investigated.

\subsubsection{Interaction between TPs and civil society}

The relationship between TPs and stakeholders has been analyzed by Campanella et al. (2014), who identified the relevance of contracts signed with local companies. Löfsten \& Lindelof (2002) and Bigliardi et al. (2006) underscored the contribution of parks for more jobs in the neighborhood. A TP influence on the place may be evaluated in terms of employment of local suppliers, generation of professional competences, new networks with local companies, scientific and cultural exhibitions promoted by the park (Bigliardi et al. 2006; Schmidt et al. 2016).

TPs may also make available sports, restaurants, shops and leisure activities to the community and neighborhood (Bigliardi et al. 2006; Schmidt et al., 2016). Table 4 provides a synthesis of the interactions between parks and civil society, following the Quadruple Helix Model.

Table 4: Interaction between TPs and Civil Society

\begin{tabular}{ll}
\hline Types of interaction with civil society & Authors \\
\hline Generation of jobs in the neighborhood & Löfsten, Lindelof (2002); Bigliardi et al (2006). \\
Increase in local suppliers & Bigliardi et al. (2006) \\
Scientific, cultural and sports activities & Bigliardi et al. (2006); Schmidt et al. (2016) \\
Generation of jobs in the park & Hommen et al. (2006) \\
Networks with local companies & Bigliardi et al. (2006) \\
Access to restaurants and shops in the park and leisure activities & Schmidt et al. (2016); Bigliardi et al. (2006) \\
Contracts with local companies & Campanella et al. (2014) \\
\hline
\end{tabular}

Source: prepared by the authors

Besides interacting with civil society, the Quintuple Helix Model, commented below, comprises the relationship between TPs and the environment.

\subsection{Quintuple Helix Model}

Promoted by Carayannis, Barth \& Campbell (2012), the Quintuple Helix Model arises from social ecology and is foregrounded on the interaction, co-development and co-evolution of society and nature. According to the authors, it is a non-linear model of innovation, combining knowledge, know-how and the natural environment system within inter- and trans-disciplinary vision. The local and the global are articulated, with sustainable activities, political and economic leadership or empowerment and the intelligent use of technology to contribute towards the sustainability challenge. The Quintuple Helix Model embodies the Triple and Quadruple Model plus the fifth helix, or 'natural environment' (Carayannis et al., 2012, p. 3). It comprises "a system of cooperation with knowledge, know-how and innovation for a greater sustainable development” (p. 4). The Quintuple Helix Model suggests such terms as 'co-innovation' and 'eco-entrepreneurship' (p. 5).

In the case of the Quintuple Helix Model, knowledge and innovation are interwoven within the economic, cultural, social, educational and political systems (Carayannis et al., 2012). The model comprises five subsystems or helixes: a) educational system, including universities and the educational system in general - human capital; b) economic system, including companies, services and banks - economic capital; c) natural environment, natural resources, plants and animals - natural capital; d) culture (traditions, values) - cultural capital and social media (TV, internet, newspapers, social network and others) - information capital; e) political subsystem, comprising legal and political capital, as plans, laws, ideas, policies etc. 
The difference between the Quadruple and the Quintuple Helix Models lies in the fact that they integrate research and development agents and agents who are not directly linked to research and development, such as hybrid institutions. The Triple Helix Model represents knowledge economy, whilst the Quadruple and the Quintuple Helix Models represent respectively the society of knowledge and the socioecology of society's natural environment (Carayannis et al., 2012).

\subsubsection{Interaction between TPs and the natural environment}

Growing concern for the natural environment and the opportunities to stimulate innovation and increase industrial efficiency triggered discussions on sustainability as an alternative in the Fifth Helix. The latter underscores the role of natural environment in society and in economy for the promotion of advances in the production, knowledge and innovation processes. It provides opportunities and responses for the issue of sustainable development with special reference to the evolution of the economy of knowledge, society of knowledge and the democracy of knowledge. Within the context of the Fifth Helix, Carayannis \& Campbell (2012: 1) remark that "the natural environments of society and economy should become drivers for the production of knowledge and innovation through defining opportunities for the economy of knowledge".

Sustainable development is one of the basic factors in the Fifth Helix Model. According to Spolidoro, Fischer \& Baron (2006), TPs are committed to sustainable development. Management activities in eco-innovation and eco-entrepreneurship are bonded to the Fifth Helix Model which comprises the preservation of natural resources and natural capital (Carayannis et al., 2012, Carayannis, Campbell, 2009 2012; Gouvea, Kassicieh, Montoya, 2013).

TPs' activities in cultural capital, such as the promotion of culture and local and regional values, are relevant for the environment (Carayannis et al., 2012). Schmidt et al. (2016) mentions areas in TPs for cultural activities and for corporative events. Lima \& Cavalcante (2005) discuss the importance of activities for the improvement of quality levels within the local life style. Table 5 presents a synthesis of these interactions.

Table 5: Interactions between TPs and the Environment

\begin{tabular}{|c|c|}
\hline Forms of interaction with the environment & Authors \\
\hline Stimuli to eco-innovation & Carayannis, Campbell (2009, 2012); Carayannis et al., (2012) \\
\hline Stimuli to eco-entrepreneurship & Carayannis, Campbell $(2009,2012)$; Carayannis et al., (2012) \\
\hline Preservation of natural resources & Carayannis et al., (2012), Gouvea, Kassicieh, Montoya (2013) \\
\hline Activities towards sustainable development & Spolidoro, Fischer, Baron (2006) \\
\hline Improvement in life quality & Lima, Cavalcante (2005) \\
\hline Promotion of culture and social values & Carayannis et al., 2012; Lima, Cavalcante (2005); Schmidt et al. (2016) \\
\hline
\end{tabular}

3.4. Synthesis of interactions between TPs and Agents, according to the innovation models

According to the interactive Triple, Quadruple and Quintuple Helix innovation models, interactions and collaborations are indispensable to enhance innovation. Social, political, institutional and cultural interactions are expected (Hommen et al., 2006). Figure 1 illustrates the possibilities of interactions between TPs and authors mentioned in the models.

Figure 1: Interactions between TPs and agents according to innovation models

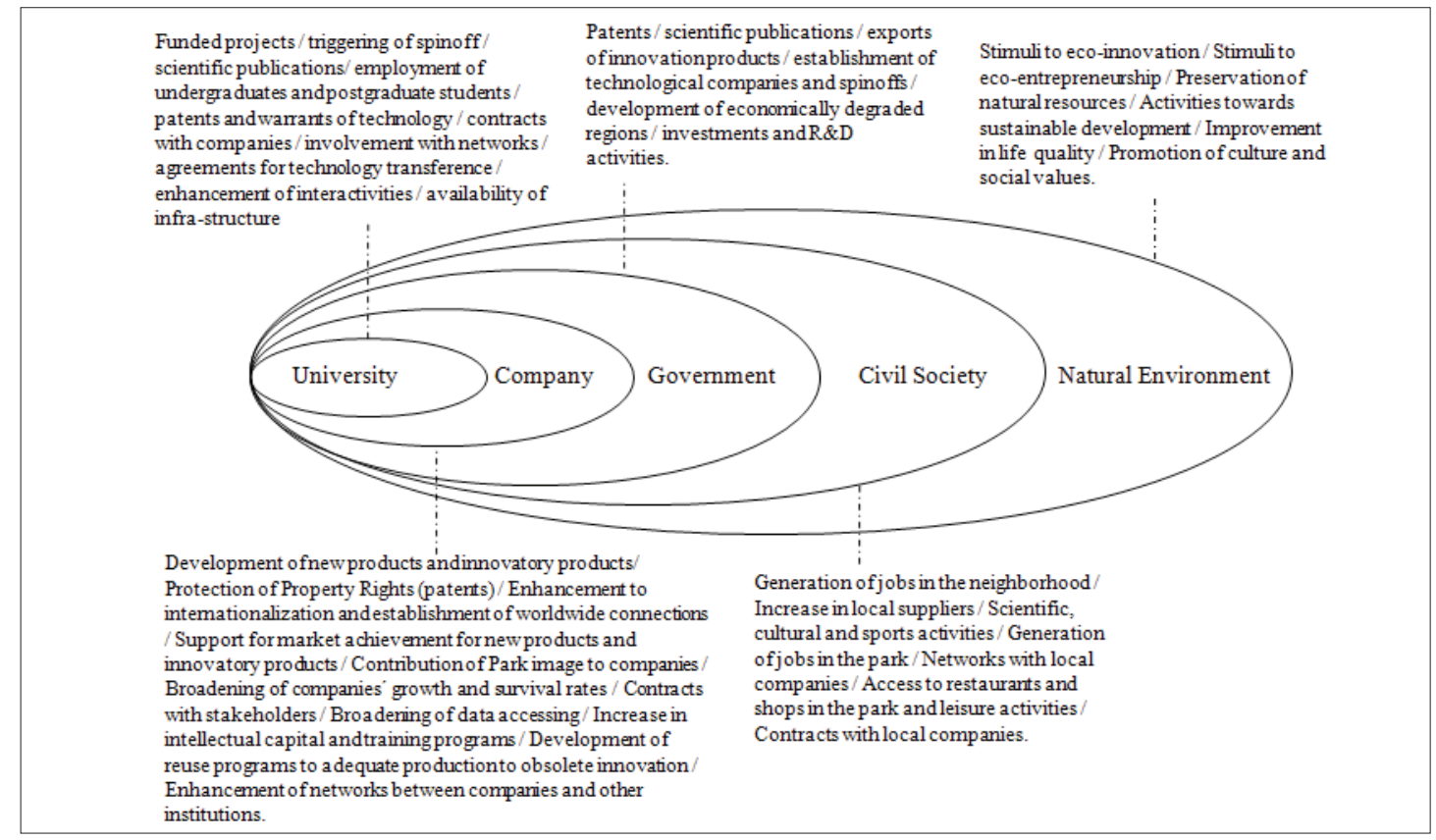

Source: Adapted from Carayannis et al. (2012) 
When one considers the set of interactions between TP and several agents, represented in Figure 1, one may notice the complexity of the institutions' management, as Bigliardi et al (2006) and Hauser et al. (2015) underscored. The relationship between TPs and agents that compose the innovation models represents an idea of innovation production and of entrepreneurship based on social, economic and environmental precepts (Belz, Binder, 2017).

The challenging role of TPs mainly consists of the production of interactions which aim at the articulation of interests given in Figure 1. Through the dynamics of such interactions, social capital is produced locally and contributes towards the generation of innovations and transformations of the environment (Julien, 2010). Consequently, civil society and innovation users have a central role in the development of innovations, as the Quadruple and Quintuple Helix Models establish (Carayannis, Rakhmatullin, 2014).

The results of current analysis may be a help to define strategies by TPs' managers and for the elaboration of management policies for stakeholders (Pacagnella Jr et al., 2015). Further, interactivities represented in Figure 1 may define the best practice for TPs (Ferrara, Lamperti, Mavília, 2016; MCTI, 2015).

The singularities of each TP must be underscored. Even if they are an institutional isomorphism (Lima, Cavalcante, 2005), they may provide variations with regard to strategy, focus, structure, management and heterogeneity of models (Vedovello, 2000; Vedovello et al. 2006). However, the interactions with several agents, as Figure 1 reveals, may be applied to any stage within the structures of TPs: planning, establishment, function or expansion (Giugliani et al., 2012).

\section{Final considerations}

Current theoretical analysis dealt with types of interactions between TPs and innovation agents within the Triple, Quadruple and Quintuple Helix Models. Consequently, interactions comprised the relationships of TPs with companies, universities, government, civil society and the natural environment.

Results show the relevance of TPs' role for the success of innovation models and, at the same time, demonstrate concern on the importance that parks should attribute to the precepts of the innovation models. It will provide them with functions within an integrating approach with the community and the natural environment. One should take into account that the interaction between agents and TPs establishes itself through the mechanisms of collaboration and the moderation of conflicts (Carayanis, Rakkamatulli, 2014; Schmidt, Balestrin, 2015).

However, it must be underscored that parks' success depends on other aspects, such as market conditions, favorable performance of the sector, government policies, laws (Lai, Shyu, 2005; Lindelöf; Löfsten, 2002) and internal competences of the established companies (Koh et al., 2005).

Among the contribution of current analysis, the interaction between TPs and agents mentioned in innovation models represent an integrating approach which is not found in previous studies. All interactions, presented in the results, favor the visualization of the parks' management dynamics and the visualization of the implementation of innovation models. Results also present subsidies for stakeholders' management and for the definition of good practices by TPs.

Current analysis is limited by the fact that the interaction types mentioned do not limit the possibilities and the new modalities may be identified in further studies to reinforce the required link between innovation models and the activities of TPs.

\section{References}

ANPROTEC. Associação Nacional de Entidades Promotoras de Empreendimentos e Tecnologias Avançadas. (2006). Panorama 2005. Retrieved from http://www.anprotec.org.br/pequisas/panorama2005.pdf . on $10 / 02 / 2006$

ANPROTEC. Associação Nacional de Entidades Promotoras de Empreendimentos e Tecnologias Avançadas. (2015). Parques \& Incubadoras para o Desenvolvimento do Brasil. Benchmarking de Sistemas Internacionais de Inovação.

Audy, J. L. N. Ambiente da inovação brasileira. Revista Locus. Anprotec, ano 20, n. 77, set. 2014.

Autio, E. (2000). Growth of Technology-based new firms. In: Sexton, D. Landström, H. Handbook of Entrepreneurship. Oxford: Blackwell Publishers.

Bellavista, J., Sanz, L. (2009). Science and technology parks: habitats of innovation: introduction to special section. Science and Public Policy, 36, (7), pp. 499-510. https://doi.org/10.3152/030234209x465543

Belz, F.M., Binder, J.K. (2017). Sustainable Entrepreneurship: A Convergent Process Model. Business Strategy and the Environment. 26, p. 1-17. https://doi.org/10.1002/bse.1887

Bigliardi, B., Dormio, A.I., Nosella, A., Petroni, G. (2006). Assessing science parks' performances: directions from selected Italian case studies. Technovation. 26, pp. 489-505. https://doi.org/10.1016/j.technovation.2005.01.002

Brasil. (2016). Presidência da República. Lei 13243 de 11 de janeiro de 2016. Retrieved from http://www.planalto.gov.br/ccivil_03/_ato20152018/2016/lei/l13243.htm

Campanella, F., Peruta, M. R. D., Giudice, M. D. (2014). Creating conditions for innovative performance of science parks in Europe. How manage the intellectual capital for converting knowledge into organizational action. Journal of Intellectual Capital, 15, (4), pp. 576-596. https://doi.org/10.1108/jic-07-2014-0085

Carayannis, E. G; Campbell, D. F. (2009). Mode 3 and Quadruple Helix: toward a 21 st century fractal innovation ecosystem. International Journal of Technology Management, 46, (3), 4, pp. 201-234. https://doi. org/10.1504/ijtm.2009.023374 
Carayannis, E. G.; Barth, T. D.; Campbell, D. F. (2012).The Quintuple Helix innovation model: global warming as a challenge and driver for innovation. Journal of Innovation and Entrepreneurship, 1, (2), pp. 1-12. https://doi.org/10.1186/2192-5372-1-2

Carayannis, E. G.; Campbell, D. F. J. (2012). Mode 3 knowledge production in quadruple helix innovation systems. 21st-century democracy, innovation, and entrepreneurship for development Springer Briefs in business, v. 7, pp. 1-63. https://doi.org/10.1007/978-1-46142062-0_1

Carayannis, E. G., Rakhmatullin. (2014). The Quadruple/Quintuple Innovation Helixes and Smart Specialisation Strategies for Sustainable and Inclusive Growth in Europe and Beyond. Journal of Knowledge Economy, 5, pp.212-239. https://doi.org/10.1007/ s13132-014-0185-8

Chan, K. F.; Lau, T. (2005). Assessing technology incubator programs in the science park: the good, the bad and the ugly. Technovation. 25, pp. 1215-1228. https://doi.org/10.1016/j.technovation.2004.03.010

Collarino, R. L. X., Torkomian, A. L. V. (2015). O papel dos Parques tecnológicos no estímulo à criação de spin-offs acadêmicas. Perspectivas em Gestão \& Conhecimento,5, (2), pp. 210-225.

Conde, M. V. F.; Araújo-Jorge, T. C. (2003). Modelos e concepções de inovação: a transição de paradigmas, a reforma de C \& T brasileira e as concepções de gestores de uma instituição pública de pesquisa em saúde. Ciência \& Saúde Coletiva, 8, (3), pp. 727-741. https://doi. org/10.1590/s1413-81232003000300007

Dettwiler, P., Lindelöf, P., Löfsten, H. (2006). Utility of location: a comparative survey between small new technology-based firms located on and off Science Parks -Implications for facilities management. Technovation, 26, pp. 506-517. https://doi.org/10.1016/j.technovation.2005.05.008

Díez-Vial, I.; Montoro-Sánchez, A. (2016). How knowledge links with universities may foster innovation: the case of Science park. Technovation, 50-51, pp. 41-52. https://doi.org/10.1016/j.technovation.2015.09.001

Díez-Vial, I.; Montoro-Sánchez, A. (2017). Research evolution in science parks and incubators: foundations and new trends. Scientometrics, 110, pp.1243-1272. https://doi.org/10.1007/s11192-0162218-5

Edquist, C. (2005). Systems of Innovation Perspectives and Challenges. In: Facerberg, J.; Mowery, D.C.; Nelson, R. R. The Oxford Handbook of Innovation. Great Britain: Oxford University Press, pp. 181207. https://doi.org/10.1093/oxfordhb/9780199286805.003.0007

Etzkowitz, H.; Leydesdorff, L. (2000). The Dynamics of innovation: from National Systems and "Mode 2" to a Triple Helix of universityindustry-government relations. Research Policy, 209, pp. 109-123. https://doi.org/10.1016/s0048-7333(99)00055-4
Felsenstein, D. (1994). University-related science parks — "seedbeds" or enclaves of innovation? Technovation, 14(2), pp. 93-110. https:// doi.org/10.1016/0166-4972(94)90105-8

Ferguson, R.; Olofsson, C. (2004). Science Parks and the Development of NTBFs- Location, Survival and Growth. Journal of Technology Transfer, 29, pp.5-17.

Giugliani, E.; Selig, P.M.; Santos, N. (2012). Modelo de governança para parques científicos e tecnológicos no Brasil. Brasília: Anprotec/SEBRAE.

Gouvea, R., Kassicieh, S., \& Montoya, M. J. R. (2013). Using the quadruple helix to design strategies for the green economy. Technological Forecasting and Social Change, 80(2), pp. 221-230. https://doi. org/10.1016/j.techfore.2012.05.003

Guan A. B.; Zhao Q. B. (2013). The impact of university- industry collaboration networks on innovation in nanobiopharmaceuticals. Technological Forecasting \& Social Change, 80(7), pp.1271-1286. https://doi.org/10.1016/j.techfore.2012.11.013

Hansson, F; Husted, K, Vestergaard, J. (2005). Second generation science parks: from structural holes jockeys to social capital catalysts of the knowledge society. Technovation. 25, (9), pp. 1039, 1049. https://doi.org/10.1016/j.technovation.2004.03.003

Hansson, F. (2007). Science parks as knowledge organizations - the "ba" in action? European Journal of Innovation Management, 10, (3), pp. 348-366. https://doi.org/10.1108/14601060710776752

Hauser, G.; Daronco, E. L.; Souza, D. O. G.; Zen, A. (2015). Capacidade de inovação de Parques Tecnológicos em países emergentes: uma proposta metodológica. Congresso Latino Americano de gestão Tecnológica, ALTEC, Anais, 2015. Porto Alegre, RS.

Hommen, L., Doloreux, D., Larsson, E. (2006). Emergence and Growth of Mjärdevi Science Park in Linköping, Sweden. European Planning Studies, 14 (10), pp. 1331- 1361. https://doi. org/10.1080/09654310600852555

Julien, P.A. (2010). Empreendedorismo e Economia do Conhecimento. São Paulo Saraiva.

Koh, F. C. C; Koh, W, T. H; Tschang, F, T. (2005). An analytical framework for science parks and technology districts with an application to Singapore. Journal of Business Venturing, 20, pp.217-239. https://doi.org/10.2139/ssrn.626361

Lai, Hsien-Che; Shyu, Joseph, Z. (2005). A comparison of innovation capacity of science parks across the Taiwan Strait: the case of Zhang Jang Hig Tech Park and Hsinchu Science-based Industrial Park. Technovation, 25, pp. 805-813. https://doi.org/10.1016/j.technovation.2003.11.004

Lastres, H. M., \& Cassiolato, J. E. (2003). Glossário de arranjos e sistemas produtivos e inovativos locais. Rio de Janeiro. 
Lee, J.; Hung, Shih-Chang. (2003). On the transformation of Science Park - The Case of The Hsinchu Science-based Industrial Park. XX IASP World Conference on Science and Technology Parks. Lisboa.

Lima, M. C.; Cavalcante, L. R. M. Teixeira (2005). Parques Tecnológicos e Desenvolvimento regional em sistemas de inovação fragmentados. XI Seminário Latino Iberoamericano de Gestion Tecnológica. Salvador

Lindelöf, P., Löfsten, H.. (2002). Growth, management and financing of new technology-based firms- assessing value-added contributions of firms located on and off Science Parks. Omega The International Journal of Management Science. 30, pp. 143-154. https://doi. org/10.1016/s0305-0483(02)00023-3

Link, A. N., \& Scott, J. T. (2006). US university research parks. Journal of Productivity Analysis, 25(1), 43-55.

Löfsten, H., Lindelöf, P. (2002). Science Parks and the growth of new technology-based firms-academic-industry links, innovation and markets. Research Policy, 31, pp. 859-876. https://doi.org/10.1016/ s0048-7333(01)00153-6

Löfsten, H; Lindelöf, P. (2004). R\&D networks and product innovation patterns-academic and non-academic new technology-based firms on Science Parks. Technovation, pp. 1-13. https://doi.org/10.1016/j. technovation.2004.02.007

Luengo, M.J.; Obeso, M. (2013). El efecto de la triple hélice en los resultados de innovación. Revista de Administração de Empresas, 53, (4) pp. 288-299. https://doi.org/10.1590/s0034-75902013000400006

McAdam, M.; Kristel, M.; McAdam, R. (2016). Situated regional university incubation: A multi-level stakeholder perspective. Technovation, 50-51, pp. 69-78. https://doi.org/10.1016/j.technovation.2015.09.002

Mian, S; Lamine, W., Fayoelle, A. (2016).Technology Business Incubation: An overview of the state of knowledge. Technovation, 50-51, pp. 1-12.

MCTI. Ministério da Ciência, Tecnologia e Inovação (2015). Estudos de práticas de parques tecnológicos e incubadoras de empresas. Brasília: 2015. Retrieved from http://www.anprotec.org.br/Relata/EstudoMelhoresPraticasParquesIncubadoras.pdf

Pacagnella Jr., A. C.; Porto, G. S.; Pacífico, O.; Salgado Jr., A.P.(2015). Project Stakeholder Management: A case study of a Brazilian Science Park. Journal of Technology, Management \& Innovation, 10, 2, p. 39 49. https://doi.org/10.4067/s0718-27242015000200004

Pessôa, L. C., Cirani, C. B. S., Silva, M. M., \& de Souza Rangel, A. (2012). Parques tecnológicos brasileiros: uma análise comparativa de modelos de gestão. RAI Revista de Administração e Inovação, 9(2), 253-273.
Quintas, P., Wield, D.; Massey, D. (1992). Academic-industry links and innovation: questioning the science park model. Technovation, 12(3), pp. 161-175. https://doi.org/10.1016/0166-4972(92)90033-e

Ribeiro, J; Higuchi, A.; Bronzo, M; Veiga, R; Faria, A. (2016) A Framework for the Strategic Management of Science \& Technology Parks. Journal of Technology, Management \& Innovation. 11, 4, p. 8090. https://doi.org/10.4067/s0718-27242016000400011

Salvador, E., Rolfo, S. (2011). Are incubators and science parks effective for research spin-offs? Evidence from Italy. Science and $\mathrm{Pu}$ blic Policy, 38, (3), pp. 170-184. https://doi.org/10.3152/01650261 $1 \times 12849792159191$

Schmidt, S.; Balestrin, A. (2015). Brazilian incubators and Science Park's Results and R \& D Collaboration. Journal of Technology, Management \& Innovation, 10, 3, p. 32-43. https://doi.org/10.4067/s0718 27242015000300004

Schmidt, S.; Balestrin, A.; Engelman, R.; Bohnenberger, M. C. (2016). The influence of innovation environments in $\mathrm{R} \& \mathrm{D}$ results. Revista de Administração RAUSP 51, pp. 397-408. https://doi.org/10.1016/j. rausp.2016.07.004

Schoonmaker, M. G., \& Carayannis, E. G. (2013). Mode 3: a proposed classification scheme for the knowledge economy and society. Journal of the Knowledge Economy, 4(4), pp. 556-577. https://doi.org/10.1007/ s13132-012-0097-4

Spolidoro, R.; Fischer, H., Baron, R. (2006).Science Parks designed as entities of the new paradigm: the Knowledge (global-based) Society. Proceedings XXII International of Science Parks - IASP World Conference, Helsinki, June 2006.

Vedovello, C. (2000). Aspectos Relevantes de Parques Tecnológicos e Incubadoras de Empresas. Revista do BNDES, Rio de Janeiro, 7,(14), pp.273-300

Vedovello, C., Judice, V., Maculan, A. M. (2006). Revisão Crítica às Abordagens a Parques Tecnológicos: Alternativas Interpretativas às Experiências Brasileiras Recentes. RAI Revista de Administração e Inovação, 3, (2), pp. 103-118.

Velho, L. (2011). Conceitos de ciência e a política científica tecnológica e de inovação. Sociologias, Porto Alegre, 13, (26), pp. 128-153. https://doi.org/10.1590/s1517-45222011000100006

Villasalero, M. (2014). University knowledge, open innovation and technological capital in Spanish science parks - Research revealing or technology selling? Journal of Intellectual Capital 15,(4), pp. 479-496.

UNESCO (2016). Science Policy and Capacity-Building. Retrieved from http://www.unesco.org/new/en/natural-sciences/science-technology/university-industry-partnerships/science-parks-around-theworld/2016. 
